RESENHAS 


\title{
RUFFATO, Luiz. Estive em Lisboa e lembrei de você. São Paulo: Companhia das Letras, 2009. 83 p.
}

\author{
Janine Resende Rocha \\ Universidade Federal de Minas Gerais
}

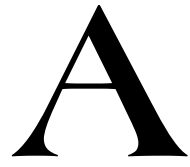

novela Estive em Lisboa e lembrei de você, de Luiz Ruffato, integra o projeto "Amores expressos", da Companhia das Letras, que apresenta a temática amorosa como clave, a ser desenvolvida pelos escritores a partir de uma viagem ao exterior. Lisboa é a cidade eleita por Sérgio de Souza Sampaio - personagem-narrador do depoimento dado a Ruffato na capital portuguesa em 2005, reproduzido de forma "minimamente editad[a]" nas páginas dessa novela. Ao mesmo tempo em que faz sobressair o pacto que o autor demanda do leitor, essa manobra ficcional enseja um recurso de verossimilhança, que faz com que o leitor aproxime a realidade narrada pela personagem da realidade extraliterária.

Dividido em duas partes, intituladas respectivamente "Como parei de fumar" e "Como voltei a fumar" (esta com o dobro exato de páginas daquela), o livro Estive em Lisboa e lembrei de você conta a vida de Serginho, como o narrador é chamado no nível diegético, ao longo de aproximadamente seis anos e meio, intervalo que separa um momento do outro. Na primeira parte, Serginho mora em Cataguases, cidade do interior mineiro onde muitas das narrativas de Ruffato são ambientadas, e vê "as coisas degringolar[em] na [sua] vida" depois de parar de fumar: um casamento, forçado pela gravidez da noiva, que se transforma num martírio; a morte precipitada da mãe; a perda do emprego numa fábrica.

Sem alento e desempregado numa cidade que não lhe oferece oportunidades para ascender socialmente nem lhe salvaguardar um futuro minimamente razoável, Serginho idealiza o "estrangeiro" como um destino promissor, com empregos e euros copiosos. A fresta para uma Lisboa fantasiosa, domicílio 
da personagem na segunda parte da novela, é motivada por seu desejo premente de se afirmar perante a sociedade, para, quando voltar de Portugal, poder andar pelas ruas cataguasenses "feito lorde, o povo todo puxando-saco, Serginho isso, Serginho aquilo, Doutor Serginho, só faltava deitarem no chão pra eu pisar em cima" (grifos do autor). Em Lisboa, porém, Serginho volta a fumar depois de passar por uma série de desventuras, que o levam a contrapor a cidade imaginada com a cidade real. Assim, o tabagismo pauta a narrativa, como se a ele estivesse atrelada uma inflexão nos rumos da vida da personagem. $\mathrm{O}$ ato de voltar a fumar vale como a sugestão de que, por mais desastrosa e frustrante que tenha sido sua ida para Lisboa, ainda é possível nutrir esperanças por um futuro mais auspicioso, desafiando o imperativo segundo o qual o transcorrer do tempo não traz melhoria alguma, e sim mais tristeza e a exacerbação da penúria e da degradação.

A Lisboa que se descortina aos olhos de Serginho, com seus cheiros e peculiaridades, é um lugar pouco hospitaleiro. Ao narrar suas perambulações pela cidade, Serginho evidencia como permanece cercado por um mundo minado, tal como era seu mundo em Cataguases, com o agravante de ser um imigrante ilegal num país estrangeiro. O contexto adverso realça uma incompatibilidade histórico-cultural - visualizada em preconceitos e estereótipos -, que acresce a condição estrangeira da personagem, qualidade que evoca um desenraizamento vivido a duras penas. Ao contrário do que se verifica em outras narrativas de Ruffato, em que o sonho de "ganhar a vida em Sampaulo" ${ }^{1}$ ou no Rio de Janeiro estimula a depreciação do espaço cataguasense, caracterizado recorrentemente pelas personagens como um "buraco" 2 onde a mediocridade prevalece, em Estive em Lisboa e lembrei de você a distância da terra natal faz com que um halo seja criado em torno dela.

Serginho é um coração simples, transviado num mundo onde tudo parece estar falido. $\mathrm{O}$ mundo talhado nessa novela reitera o universo narrativo consolidado por Ruffato tanto no romance Eles eram muitos cavalos como nas narrativas que compõem a série "Inferno Provisório", em que as mazelas impressas no cotidiano reles das personagens transformam o mundo num inimigo

\footnotetext{
${ }^{1}$ RUFFATO, 2001, p. 17.

${ }^{2}$ RUFFATO, 2005, p. 65.
} 
efetivo. Essa hostilidade, já indicada nos títulos dos volumes dessa série $O$ mundo inimigo, Vista parcial da noite e $O$ livro das impossibilidades -, traduz uma configuração aporética de tal universo, que acaba por sinalizar certa ironia no provisório desse inferno, pois, pelo visto, o calvário só acaba com a morte. Por mais que se tente ir contra a origem ${ }^{3}$ e mesmo que a mixórdia existencial aproxime as personagens de um estado repugnante, toda tentativa de esquecer, negar ou transformar o lugar da origem, com seu traçado de pobreza e exclusão social, terá um resultado vão.

As histórias de amor relatadas por Serginho, inexoravelmente definidas pela decepção, pelo engano e interesses escusos, reforçam o quinhão dramático que cabe à personagem suportar. O destino de penúria de Serginho continua a ser projetado em Lisboa, onde suas aspirações não encontram amparo, impedindo o retorno à província. Revivida com melancolia em meio às sombras de uma realidade ausente, Cataguases, a terra louvada pelo narrador como "terra de gente ordeira e trabalhadora”, é apenas uma fotografia na lembrança. O desejo maior de "virar gente importante" no interior é erodido pelo "desalento imigrante de quem sabe que de nada serve essa vida se a gente não pode nem mesmo aspirar ser enterrado no lugar próprio onde nasceu".

Mais do que uma coletânea de histórias de amor fracassadas, Estive em Lisboa e lembrei de você aviva um tema caro à literatura de Ruffato: a busca por melhores condições de vida através da imigração. Estratégia adotada por Serginho e por tantas personagens que cruzam seu caminho em Lisboa, a imigração provoca um lamento imantado pela saudade da pátria e pela perda de identidade suscitada pelo êxodo. Perda concretizada, inclusive, por meio da alteração lexical, pois o destaque angariado pelo campo semântico lisboeta, na segunda parte da novela, extrapola o registro da dicção portuguesa, e aguça ainda mais o desarraigamento da personagem. Contudo, antes de gerar uma desagregação que não existia, a imigração tenta calar um velho lamento: o da negativa à inclusão social. Apesar desses lamentos e dos redemoinhos do próprio desejo, engenhosamente retratados no livro, Serginho não perde a ternura.

\footnotetext{
${ }^{3}$ Nessa direção, as narrativas "Amigos" e "A demolição", de $O$ mundo inimigo, são paradigmáticas.
} 


\section{Referências bibliográficas}

RUFFATO, Luiz. Eles eram muitos cavalos. São Paulo: Boitempo, 2001.

RUFFATO, Luiz. O mundo inimigo. Rio de Janeiro; São Paulo: Record, 2005. (Inferno Provisório, v. II) 